314.151.3-054.73-053.2(495.6:=163.3):37.018-58.862(438)"1959/1960"

172.15:314.151-054.73-053.2(438)

Едвард Кањук (Полска)

Ана Курпиел, уредник (Полска)

Центар Вили Брант за германски и европски студии

Универзитет во Вроцлав

Е-маил: anna.kurpiel@uwr.edu.pl

\title{
НАЦИОНАЛНИТЕ ЧУВСТВА НА ГРЧКИТЕ И МАКЕДОНСКИТЕ ДЕЦА БЕГАЛЦИ ОД ДРЖАВНИОТ ОБРАЗОВЕН ЦЕНТАР ВО ПОЛИЦЕ
}

Апстракт: Текстот содржи извадоци од магистерскиот труд одбранет во 1962 година во Полска. Авторот бил едуктарот и учител во Државниот едукативен центар за деца-бегалци во градот Полице. Овој труд, кој го вклучува проблемот со националната свесност на грчките и македонските деца и нивните меѓусебни врски, претставува важен извор за истражување на децата-бегалци од грчката граѓанска војна во Европа.

Клучни зборови: деца-бегалци, грчката Граѓанска војна, Државен училишен центар, студии за детството, Народна Република Полска

\section{Вовед}

Презентираниот материјал е избор од магистерски труд напишан на почетокот на 1960 година под менторство на проф. Јозеф Квјатек од Универзитетот,Адам Мицкевич“ од Познањ, Полска.

Автор на магистерскиот труд бил тогашниот млад едукатор, а подоцна наставник, кој работел во Државниот образовен центар (ДОЦ) за децата бегалци од Граѓанската војна во Грција. Неговото искуство е евидентно од текстот, и тоа е дополнителна вредност на анализираниот истражувачки материјал.

Опишаниот ДОЦ бил лоциран во еден мал полски град Полице во комплекс згради адаптирани од поранешната фабрика за синтетички бензин. Во 1951 година, по летните одмори, речиси сите деца бегалци биле преселени таму од Државниот образовен центар во Згожелец.

Еве што пишува Едвард Кањук за Државниот образовен центар (ДОЦ) во Полице: 
„Објекйи изг̄раgени оg Германцийе за време на

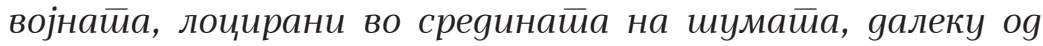

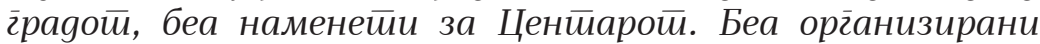

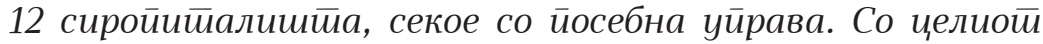

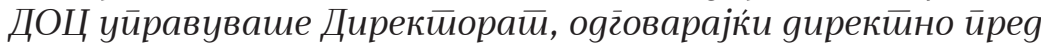
Минисиерстивойо за образование. Sиg го ойкружуваше

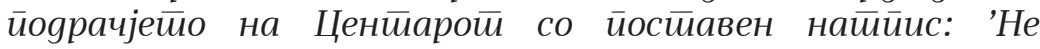
e gозволено за сииранци'. Беше како gейски іраg.

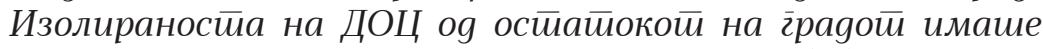
сериозни йослеgици за меѓусебнииее оgноси (...) Гоgинийе og 1952 gо 1954 беа йериоg на најїолем развој на Ценйарой

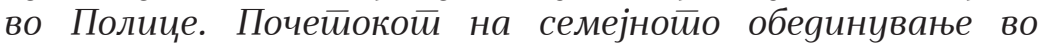

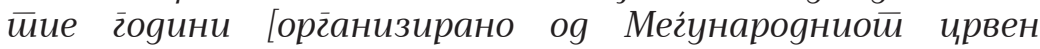

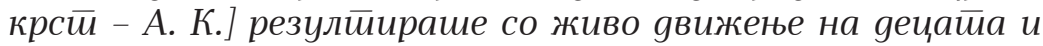

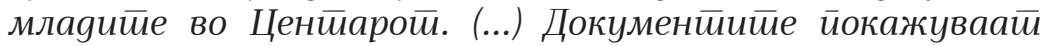
gека во учебнайа 1952/1953 гоgина имало 1301 ученик во Ценйарой. Во учебнайа 1953/1954 гоgина овој број се искачил на 1435 ученици. Биле оргіанизирани тири основни

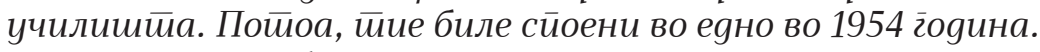
Og 1955 голина, бројой на деца йосииейено се намалувал.“

Магистерската работа, која не е објавена претходно, е пишувана на машина за пишување, на 68 страници. Копија од авторот добив за време на нашиот состанок во Полице во 2010 година. Во текстот има упатувања кон додатоците (на пример, есеи на ученици или извештаи на наставници). Сепак, во мојата верзија на магистерската работа тие недостасуваат.

Текстот е поделен на вовед, четири поглавја и заклучок. Првото поглавје ја содржи историјата на доселувањето на македонските и на грчките деца бегалци во Полска, потоа претставување на предметот на истражувањето, методологијата и преглед на литературата. Следните три поглавја се засновуваат на истражувањето на авторот и вклучуваат дискусија за националната свест на децата (поглавје 2); националната свест и социјалната поврзаност во рамките на групата (поглавје 3) и за нивната национална свест и ставовите кон Полска (поглавје 4).

Можеме да претпоставиме дека магистерскиот труд на Едвард Кањук бил првото аналитичко дело за македонските и грчките бегалци во Полска ${ }^{1}$. Напишан е повеќе од десет години по присилната миграција и населувањето во нова земја. Во тоа време, соништата за нивно скоро враќање во Грција веќе биле заборавени, и започнал процесот на адаптација.

1 Покрај официјалните извештаи и приватните белешки на Вацлав Копчињски, кој бил одговорен за создавањето и организирањето на центрите во име на Министерството за образование. 
Како што истакнал авторот, никој дотогаш не ја анализирал критичната прва деценија од престојот на бегалците во Полска. Освен официјалните документи, немало опис за децата бегалци помеѓу нивното пристигнување во Полска и времето кога е напишана тезата. Затоа, недостасуваат информации за адаптацијата и интеграцијата на најстарите деца во групата. Едвард Кањук главно работел со деца што едвај се сеќавале или воопшто не се сеќавале на нивната родна земја и на нивните села. Тие пораснале во реалноста на полскиот Државен образовен центар.

Магистерскиот труд е оригинален и уникатен документ. Ограничувањето за должината на статијата не дозволува вклучување на целиот текст. Направив независен и субјективен избор на извадоци за превод и објавување. Избрав фрагменти што го елаборираат сопственото истражување на Кањук и неговите резултати. Исто така, ја зедов предвид потенцијалната корисност на текстот за понатамошно истражување на националниот идентитет на македонските и грчките бегалци, на грчко-македонските меѓусебни односи или на организацијата на школувањето и образованието на децата во Полска.

\title{
Едвард Кањук
}

НАЦИОНАЛНА СВЕСТ НА ГРЧКИТЕ И МАКЕДОНСКИТЕ ДЕЦА БЕГАЛЦИ ОД ДРЖАВНИОТ ОБРАЗОВЕН ЦЕНТАР ВО ПОЛИЦЕ

\author{
Полице, 1962 година
}

\section{Поглавје 1}

\section{(...)}

\section{Предмет на истражување}

Целта на оваа студија е да се испита состојбата на националната свест и општествените ставови на грчките и македонските деца ученицивоДржавниотобразовенцентарвоПолице.(...)Истражувањето е спроведено во учебната 1959/1960 година, главно во училиштето и во домовите за деца без родители. Основното училиште број 4 во Полице беше до 1 септември 1958 година үчилиште во Државниот образовен центар. Таму учеа грчки и македонски деца. Поради намалувањето на бројот на деца, Центарот го укина сопственото училиште и одлучи да му го предаде на просветниот инспектор. Училиштето стана обично основно училиште, со само некои измени во распоредот што произлегоа од дополнителните часови по грчки и македонски јазик. 
Каква беше организацијата на училиштето во учебната 1959/1960 година, т.е. во времето на истражувањето?

Училиштето имаше 22 групи. 8 од нив беа грчки групи во одделенија од I до VII одделение (со две паралелни групи во VI одделение). Имаше 7 македонски и 7 полски групи (од I одделение до VII одделение) $)^{2}$.

Во училиштето имаше вкупно 497 ученици:

Македонци 84

Грци 192

Полјаци 271.

Во училиштето работеа 22 наставници, од кои тројца Грци и еден Македонец. Двајца Грци се квалификувани стари учители од Грција. Третиот има општо средно образование и прва година на Земјоделскиот универзитет во Грција. Македонскиот наставник има завршено средно училиште. Овие наставници предаваа грчка историја и географија, како и мајчин јазик.

Другите предмети во грчките групи ги предаваа полски наставници. Бидејќи предмет на истражување се грчките и македонските деца, ќе презентирам список што ќе ги даде најопштите информации за нив.

Грчки деца во учебната 1959/1960 година:

Возраст на децата

\begin{tabular}{|l|l|l|l|l|l|l|l|l|l|l|}
\hline $\begin{array}{l}\text { Годнна } \\
\text { на } \\
\text { раѓање }\end{array}$ & 1952 & 1951 & 1950 & 1949 & 1948 & 1947 & 1946 & 1945 & 1944 & Вкупно \\
\hline $\begin{array}{l}\text { Број на } \\
\text { деца }\end{array}$ & 10 & 17 & 22 & 20 & 17 & 21 & 24 & 39 & 22 & 192 \\
\hline
\end{tabular}

Пол

$\begin{array}{ll}\text { Женски } & 95 \\ \text { Машки } & 97 \\ \text { Вкупно } & 192\end{array}$

Општествено потекло

$\begin{array}{ll}\text { Селани } & 106 \\ \text { Работници } & 52 \\ \text { Интелектуалци } & 32\end{array}$

2 Во тоа време, полскиот образовен систем опфаќал основно үчилиште со седум одделенија (од I одделение до VII одделение), а потоа стручно училиште или четиригодишно средно училиште (од VIII одделение до XI одделение).

3 Врз основа на училишната документација што се користи во училишната хроника (прилог број 14). 
Услови во семејството

Деца без родители 12

Деца без еден родител 89

Деца со родители 91

Место на раѓање

Во Полска 49

Во Грција 137

Друго 6

2. Македонски ученици во учебната 1959/1960 година"

Возраст на учениците

\begin{tabular}{|l|l|l|l|l|l|l|l|l|l|l|}
\hline $\begin{array}{l}\text { Година на } \\
\text { раѓае }\end{array}$ & 1952 & 1951 & 1950 & 1949 & 1948 & 1947 & 1946 & 1945 & 1944 & Вкупно \\
\hline $\begin{array}{l}\text { Број на } \\
\text { деца }\end{array}$ & 2 & 3 & 7 & 10 & 12 & 17 & 16 & 10 & 7 & 84 \\
\hline
\end{tabular}

Според пол

Женски 46

Машки 38

Вкупно 84

Општествено потекло

Селани 61

Работници 9

Интелектуалци 14

Услови во семејството

Деца без родители 7

Деца без еден родител 24

Деца со родители 53

4 Врз основа на училишната документација што се користи во училишната хроника (прилог број 14). 
Место на раѓање

Во Полска 17

Во Грција 52

Друго 15

Од вкупниот број 276 грчки и македонски деца од Основното училиште број 4 во Полице, 230 живеат во сиропиталишта на Државниот образовен центар во Полице, а 46 живеат со своите родители во градот Полице.

\section{Поглавје 2}

Карактеристики на националната свест и социјалните ставови на децата од Државниот образовен центар во Полице во учебната 1959/1960 година

Додека се дискутира за симптомите на интерес во земјата домаќин, мора да се наведе дека тие се манифестираа во широк спектар на форми. Систематското набљудување во учебната 1959/1960 година го потврдува ова.

Резултатите од набљудувањата покажуваат дека децата се заинтересирани за нивната родна земја. Кој е резултатот од овој интерес или што знаат децата за Грција? Јас го испитав ова прашање со анализа на есеите и цртежите на децата (...). Темата на есејот: „Што знам за мојата татковина?“(...)

Во 112 од 114 есеи на грчките деца постои директна изјава дека татковината им е Грција. Во два труда Полска е претставена како татковина [деца од мешани грчко-полски бракови - заб. Ана Курпиел].

Од вкупно 68 есеи на македонски деца, во 24 има одговор дека нивна татковина е Македонија. Тоа е 35,3 \% од вкупниот број искази. Еве поинтересни цитати: „Мојата родна земја е Македонија. Македонија не постои денес. Таа е поделена помеѓу Грција, Југославија и Бугарија. Исто така, знам дека Грција го окупирала најголемиот дел од Македонија, и таму има многу Македонци. Сега, во Грција, им е дозволено на Македонците да зборуваат на нивниот мајчин јазик. Македонците, заедно со грчките работници, се борат за независност на Македонија и на Грција“.

Ученик од VII одделение напишал: „Мојата татковина е (Македонија) Грција“. Түка може да се види афектната приврзаност 
кон Македонија, а потоа и рационалниот одраз дека Македонија не постои, па ученикот ја поправил во „Грција“.

Ученик од VI одделение: „Македонија е моја татковина. Прашањето е за Грција, а не за мојата татковина. Јас ќе одговорам на прашањето - што знам за Грција“.

Од погоре презентираните есеи може да се види дека знаењето на децата за татковината е нецелосно и хаотично (...). Сепак, можеме да претпоставиме дека децата знаат различни факти за минатото на Грција. Тие ја покажуваат нејзината величина и слава во античко време. Тие споменуваат познати луѓе од тоа време. Тие даваат многу факти од периодот на битките со Турците и Втората светска војна. Тие ги споменуваат имињата на националните херои: Гоце Делчев, Даме Груев, Јане Сандански, Лазо Трповски, Никос Белојанис, Манолис Глезос и други. (...)

Прашалниците, исто така, илустрираат манифестации на интерес кон нивната родна земја, како и состојбата со вестите за неа. Првите три прашања од истражувањето на децата во 1959/1960 година беа прецизно наменети за разјаснување на овие прашања.

Во врска со ова прашање на истражувањето, треба да се покаже една интересна опсервација што може да се сумира на следниов начин: „повеќето грчки деца сакаат да се вратат во Грција, додека повеќето македонски деца сакаат да останат во Полска или да заминат во друга социјалистичка земја“. (...)

Оваа споредба покажува дека 64 \% од Македонците не размислуваат за враќање во Грција, а соодветниот процент на грчки деца е 34,6 \%. Може да се види дека грчките деца се емотивно поповрзани со својата татковина и таму ја гледаат својата иднина. Фактот дека Македонците не ја сакаат Грција и Грците е добро познат во егзил, иако официјално е изоставен или прикриен. (...)

Кога се дискутира за состојбата на знаење за родната земја, треба да се цитираат одговорите на прашањето: „Кој е вашиот омилен херој и зошто?“

Деведесет и пет деца, тоа е $60 \%{ }^{5}$, наведуваат лик од современа Грција како нивен херој. Во 38 одговори, односно 21,7 \%, е наведен лик од Полска. Во 16 одговори - 9,1 \% - од СССР. Останатите проценти, а тоа се 22 одговори, означуваат херој од други земји, а 4 одговори херој од Античка Грција.

Фактот дека мнозинството деца го гледаат својот херој во современ грчки лик е израз на големото влијание на настаните во Грција за време и по Втората светска војна.

Во оваа група деца, испитаниците најмногу ја наведуваат фигурата на Манолис Глезос. „Мојот омилен лик е Манолис Глезос. Тој е национален херој на Грција. Тој се бореше за слободата и правата

5 Би требало да биде 54,6 \%, заб. Ана Курпиел. 
на нацијата. Тој ги знаеше животите на сиромашните; затоа, тој се бореше за подобрување на нивниот живот.“

Вториот омилен лик на децата е Никос Белојанис. „Мојот омилен херој е Никос Белојанис затоа што се бореше за грчките работници и селани. Сепак, тој не ги заврши своите намери затоа што беше заробен и умре мислејќи на Грција.“ (...)

Со цел да ги презентираме прашањата од интерес за нас поцелосно, треба да се анализираат факторите на образование на децата и, пред сѐ, да се обрне внимание на резултатите од учењето на мајчиниот јазик.

Значењето на мајчиниот јазик во услови на престој на децата во егзил не треба да се објаснува.

При организирање на основното образование на децата бегалци во ДОЦ во Полице, била земена предвид потребата од образование на мајчин јазик и затоа постоела настава на мајчин јазик. (...) Веќе неколку години организацијата на училиштето и бројот на часови по јазик е како што следува подолу:

Грци

Прво одделение - настава на грчки јазик;

Второ одделение - настава на грчки јазик и 5 часа неделно на полски јазик како предмет;

Трето одделение - настава на полски јазик и 6 часа неделно на грчки јазик;

Од четврто до седмо одделение - како во трето одделение.

Македонци

Прво одделение - настава на македонски јазик;

Второ одделение - настава на македонски јазик и 5 часа неделно на полски јазик како предмет;

Трето одделение - настава на полски јазик и 8 часа неделно на македонски јазик;

Од четврто до седмо одделение - настава на полски јазик, 6 часа неделно македонски јазик и 2 часа неделно грчки јазик како предмет.

Од вкупниот број часови за мајчин јазик, наставникот посветува одреден дел за историјата и географијата на Грција. (...)

Анализата [на оценките на учениците по предметите грчки, македонски и полски јазик-заб. Ана Курпиел] овозможува да се открие, барем делумно, односот на децата кон мајчиниот јазик. Евидентно е дека децата имаат подобри оценки на нивниот мајчин јазик отколку за полскиот јазик. Што се однесува до македонските деца, постои 
карактеристичен феномен на совпаѓање на бројот на слаби за полски и за грчки јазик. На крајот од учебната година излегува дека овие деца може да имаат подобри оценки за грчки јазик. Можеме ли од ова да заклучиме дека македонските деца го сметаат грчкиот за странски јазик? Само врз основа на овие податоци, таквиот заклучок би бил премногу избрзан. Сепак, материјалите добиени како резултат на други методи дозволуваат, па дури и наведуваат дека треба да се земе предвид оваа можност 6 . Феноменот на добивање подобри оценки за грчки јазик отколку за полски јазик е видлив и кај грчките деца.

\section{Поглавје 3}

\section{Националната свест и социјалната врска во рамките на групата}

Целта на поглавјето е да се покаже како националната свест и патриотските чувства влијаат врз обликувањето на социјалните врски во групата. Тука мислам на влијанието на овие фактори врз формирањето на колективот на учениците во училиштето и на групата пријатели надвор од училиштето. (...)

Како влијае националната свест врз социјалната врска во групата анкетирани деца? Во 1951-1958 година, во ДОЦ и во Основното училиште број 4 во Полице имало само грчки и македонски деца. Постепено, оваа ситуација се сменила [кога почнале да се примаат полски деца во училиштето - заб. Ана Курпиел].

Приемот на полски деца во Центарот и во училиштето означил почеток на пошироки општествени контакти меѓу грчките и македонските деца, кои, до 1958 година, живееле во изолирана средина, одржувајќи само повремени врски со полската заедница. (...)

Ги испитав односите во групата деца со анализа на одговорите на прашањето: „Кои тројца соученици ви се допаѓаат најмногу и зошто?“"

Во ноември 1960 година собрав одговори од две групи (од петто одделение и од шесто одделение). Обрнав внимание главно на овие групи затоа што тие се мешани грчко-македонски. Целта ми беше да откријам кои се причините за заемното разбирање помеѓу нив.

Од петтоодделенците добив 10 одговори од Македонци и 9 од Грци. Во шесто одделение добив 14 одговори од Македонци и 16 од Грци.

Меѓу одговорите во петто одделение има три одговори од девојчиња и седум од момчиња (се однесува на Македонците).

6 Ќе се навратам на ова прашање во следното поглавје кога ќе зборувам за односите во групата грчки и македонски деца. 
Бројот на гласови за одделни ученици како најпосакувани е како што следува подолу:

1. Момче (Македонец).......

2. Момче (Македонец).........

3. Девојче (Македонка)

4. Момче (Грк)

5. Девојче (Гркинка)

Вкупно
10 гласа

8 гласа

6 гласа

4 гласа

2 гласа

30 гласа

Децата даваат различни причини за симпатии како „пријателски“, „добар ученик“, „добар спортист“, но, меѓу 49 одговори од двете групи, „националноста“ на пријателот никогаш не била посочена како причина за симпатии. Сепак, тоа е забележано и со фактот што, кај петтоодделенците, петмина Македонци добиваат 14 гласа од Грците од 27 можни, а кај шестоодделенците - 17 гласа од 48 можни. Истовремено, Грците во овие групи добиваат многу помал број гласови од Македонците - во петто одделение - 6 гласа од 30, во шесто одделение - 6 гласа од 42.

Истражуваните материјали се недоволни за да се направат општи заклучоци од нив. Сепак, треба да бидат индикатори за натамошно набљудување: македонските деца во изучуваните групи се водени од нивната националност во поголема мерка при идентификувањето на најпосакуваните колеги од грчките студенти, кои барем во истражуваните групи немаа прифатено таков став. (...)

Набљудувањето разни спортски настани во училиштето обезбеди дополнителен материјал. Кога игра македонско одделение на ракометните игри, Македонците од другите групи ги бодрат и покажуваат голема радост за нивниот успех.

Македонските деца доброволно настапуваат на училишните церемонии со поеми и песни на својот јазик. Ова првенствено се однесува на прослави на разни грчки јубилеи, како што е годишнината од ослободувањето на Грција од турското владеење или годишнини од востаничките борби.

Кај постарите младинци, поделбата во две национални групи, обликувани според националната свест и патриотските чувства, е појасно видлива. За време на подготовката на програмата за 10-годишнината од постоењето на Центарот во Полице, во јуни 1961 година, за малку ќе дојдеше до тепачка меѓу грчката и македонската младина околу спорот на кој јазик треба да се игра сцената од периодот на герилските борби во Грција. Аргументите на обете страни беа интересни. Македонците инсистираа дека партизаните зборуваа првенствено на македонски, додека Грците инсистираа на 
тоа дека најважен јазик е грчкиот. На крајот, наставникот задолжен за подготвување на програмата мораше да предложи компромисен излез од проблематичната ситуација затоа што ниту една од страните не сакаше да отстапи со закана дека ќе се откаже од претставите. Децата играа еден фрагмент на грчки, а другиот на македонски јазик.

Децата на училиште широко го коментираа овој настан. Во дискусиите, децата користеа слични аргументи како учесниците во спорот. Може да се види дека постојната национална поделба станува поочигледна секогаш кога станува збор за патриотските чувства и националната гордост.

\section{Заклучоци}

Спроведеното истражување овозможува да се изведат следниве општи заклучоци:

1. Националната свест и социјалниот став се различни кај децата што се сеќаваат на нивната родна земја и кај оние што ја напуштиле својата татковина во раното детство или се родени во други земји.

2. Националната свест и патриотските чувства играат улога во меѓусебните односи на децата, предизвикувајќи зголемена меѓусебна солидарност и подготвеност да си помагаат едни на други.

3. Политичките, општествените и економските услови на живот во Полска влијаат врз навиките на емигрантите. Обичаите, чие продолжување во полски услови е проблематично од различни причини, исчезнуваат, и се случува усвојување на полските обичаи. Тоа е особено видливо во случајот со семејните прослави.

4. Ненаклоноста на Македонците кон Грците, која има извор во сегашната политичка состојба во Грција, се рефлектира и кај иселениците од таа земја во Полска. Иако обете страни се обидуваат да ја сокријат оваа нетрпеливост, и возрасните и децата емигранти во основа се поделени во две групи: Македонци и Грци. Овој факт има сериозни последици во обликувањето на меѓусебните односи.

5. Постепено, со текот на времето, се зголемува интересот за земјата во која живеат емигрантите. Овој раст, особено видлив кај децата, има сериозно влијание врз односот кон Полска, што доведува грчките и македонските деца да ја признаваат како нивна втора татковина. 
ЕтноАнтропоЗум
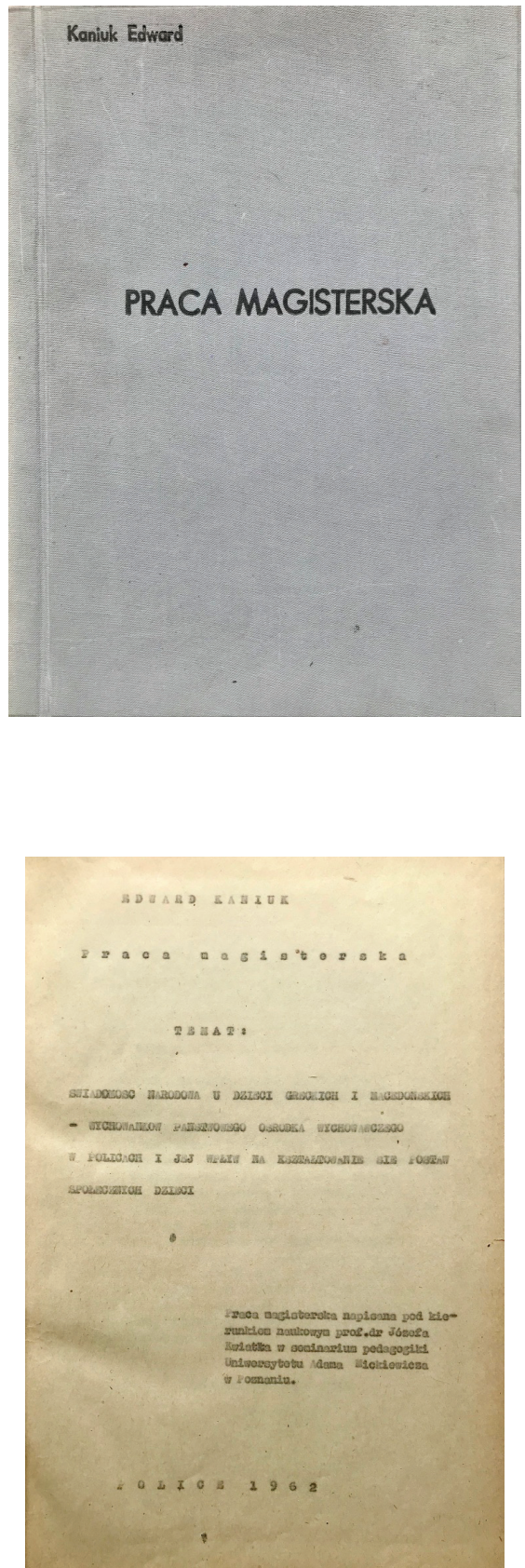

Факсимил од магистерската работа на Едвард Кањук 